Appleton has achieved renown in two spheres, either of which might be considered as forming a sufficiently full life for a lesser man of science. He has for more than a quarter of a century been the most active worker in the field of radio physics, and during this period he has conducted research work of the most far-reaching importance. Since 1939, also, he has been secretary of the Department of Scientific and Industrial Research, a position which gives him the responsibilities and duties of the leading man of science in the Government service of Britain. Appleton displayed his great scientific ingenuity and experimental skill in December 1924, when he demonstrated the existence of the Heaviside layer as an ionized region of the atmosphere capable of reflecting electromagnetic waves. Shortly afterwards, he discovered another and higher region-the Appleton layer-from which the shorter radio waves are reflected after they have penetrated the lower region. From that time onwards Appleton has conducted a continuous series of researches on the characteristics of the ionosphere, and the part they play in determining the mode of propagation of radio waves round the earth. The techniques developed in the course of these investigations provided the foundations for the development of radar in Great Britain, while the results of the research on the ionosphere have proved invaluable in forecasting and allocating the most suitable frequencies for practical radio communication, broadcasting and other applications. More recently, Sir Edward Appleton, in cooperation with other workers, has devoted attention to the reflexion of radio waves from meteors, and has demonstrated that sunspots are powerful sources of very short radio waves.

His work during the war years as secretary of the Department of Scientific and Industrial Research was particularly onerous for, in addition to conducting the normal activities of the Department, he was called upon in 1941 to advise the Government on the magnitude of the effort to be devoted to the exploitation of nuclear energy, and later to set up a special section of the Department to carry out the necessary research work forming the British contribution to the development of the atom bomb. Sir Edward, who was elected a fellow of the Royal Society in 1927, has received many honours and awards in Great Britain and overseas, and he has been president of the International Scientific Radio Union since 1934.

\section{Royal Society: Medal Awards}

His MAJESTy THE KING has approved the recommendations made by the Council of the Royal Society for the award of the two Royal Medals for the current year as follows :

Prof. C. N. Hinshelwood, Dr. Lee's professor of chemistry, University of Oxford, for his distinguished work on the mechanism of chemical reactions, from the simplest gas phase processes to the complexities of cell division ;

Dr. F. M. Burnet, director of the Walter and Eliza Hall Institute for Medical Research, Melbourne, for his distinguished work on bacteriophages, viruses and immunity; and for his contributions to the study of infectious disease as an ecological phenomenon.

The following awards of medals have been made by the President and Council of the Royal Society :

Copley Medal to Prof. G. H. Hardy, emeritus professor of pure mathematics, University of Cambridge, for his outstanding part in the development of mathematical analysis in Britain during the last thirty years ;

Davy Medal to Prof. L. C. Pauling, director of the Gates and Crellin Laboratories, California Institute of Technology, for his distinguished contributions to the theory of valency and for their application to systems of biological importance;

Buchanan Medal to Sir Edward Mellanby, secretary to the Medical Research Council, for his distinguished researches on the physiology of nutrition, especially in relation to the causation of deficiency diseases ;

Hughes Medal to Prof. J. F. Joliot, director of the National Centre of Scientific Research, Paris, for his distinguished contributions to nuclear physics, particularly the discovery of artificial radioactivity and of neutron emission in the fission process.

\section{Physiology at St. Thomas's Hospital Medical School: Prof. H. Barcroft}

Prof. Henry Baroroft, Dunville professor of physiology, Queen's University, Belfast, has recently been appointed to the University chair of physiology in St. Thomas's Hospital Medical School, London. Prof. Barcroft is a son of the late Sir Joseph Barcroft of Cambridge, and was educated at Marlborough College and King's College, Cambridge. He held the Harold Fry and George Henry Lewis studentships at Cambridge during 1927-29 and was awarded the Gedge Prize in 1930. He qualified in medicine at St. Mary's Hospital, London, after which he was appointed lecturer in physiology at University College, London, a post which he occupied from 1932 until 1935 . $\mathrm{He}$ has held the chair of physiology at Queen's University, Belfast, from 1935 until the present time, and has carried out distinguished work on the control of the vasomotor system, and of the blood flow to the limbs and other parts of the body. His experiments were mainly carried out on the human subject and involved important observations on the physiology of syncope.

\section{Jubilee of the Discovery of the Electron}

THE fiftieth anniversary of the discovery of the electron was recently marked in Cambridge by an open meeting of the Philosophical Society at which a lecture on the history of the Cavendish Laboratory was given by Dr. Alex. Wood in that Laboratory. Dr. Wood was himself a research student under Sir J. J. Thomson and has been closely associated with the teaching work of the Cavendish Laboratory since 1905. His lecture was illustrated by exhibits of historical apparatus used by Clerk Maxwell, Rayleigh, Thomson and Rutherford. Among guests present were Dr. G. F. C. Searle, who as a boy was shown round the Laboratory by Clerk Maxwell shortly after it was built; Mr. J. E. Rolph, who was appointed as laboratory assistant by Lord Rayleigh in 1881; Mr. F. J. Lincoln, who was a laboratory assistant for fifty-three years, including forty-two years as steward; Sir William Dampier, who as W. C. D. Whetham joined the Laboratory in the very early days of Sir J. J. Thomson's professorship ; and Lady Thomson, who as Miss Paget was a research student in 1889 and was married to J. J. Thomson in 1890 .

\section{British Books for Germany}

AT the Information Centres of the Control Commission in the British Zone of Germany reference books are available for those who live near enough; 
and special arrangements are planned for educationists and writers of school and university text-books. British books cannot, however, be purchased by Germans. The Control Commission has officially approved a scheme, put forward by the Agency for Intellectual Relief in Germany, under which the Agency will establish lending libraries for British books in key-centres of the British zone. The first library, containing some four thousand books, is being opened in Hamburg. Once the libraries have been established, German committees in each town will take over the management; it is expected that current expenditure in Germany will be covered by the borrowers' fees. A list of books needed, based on suggestions by German readers, has been prepared. Contributions are solicited towards the cost of books that must be bought; cheques should be sent to the honorary treasurer of the Agency for Intellectual Relief in Germany, C. P. Kininmonth, 4 Chapel Row, Wheeler End, High Wycombe, Bucks. Information relating to the scheme can be obtained from the Agency for Intellectual Relief in Germany, Foreign Office, German Section, 48 Prince's Gardens, London, S.W.7.

\section{Import of Scientific and Technical Books}

Replying to a question in the House of Commons, the President of the Board of Trade stated that he is prepared to consider the issue of licences for limited additional imports of technical and scientific books in English from certain European countries. Similar books in foreign languages from non-English speaking countries are licensed freely.

\section{German Hydrographic Institute, Hamburg}

Tre first annual report of the German Hydrographic Institute, Hamburg, consists of a 64-page booklet both in German and English (the former language being that of the official text). It gives a good account of the provision which has been made in Germany since the War for the performance of the various tasks formerly undertaken by the organisation which was the German analogue of the Hydrographic Department of the British Admiralty. Along with that account, which tells of work to do with marine surveying, the making and printing of nautical charts, the issue of nautical books, the testing of compasses, the observation and publication of magnetic values, the issue of time signals, and with many other matters concerning which information is needed by mariners and required by the naval side of the Allied occupying authority, there is substantial information bearing upon the present state of German oceanography.

Before the War, the science of oceanography had numerous practitioners in Germany, and, in addition to the two well-known and very large organisations devoted to its furtherance, there were several small scientific bodies of repute which worked in this sphere. The report records how plans were laid for the em. ployment of about one-fifth of the large number of oceanographers to work upon tasks which should serve the interests of, and meet the needs of, that rump organisation which-it was approved by the Allied Control Council-had to be set up to carry out essential hydrographical duties in German waters. These scientific workers ultimately became Section 2 of the Institute which is the subject of the report. This, established initially by the British naval authorities, is now under the governance of a quadripartite board of four directors, functions in Hamburg, and is 'managed' by the British director, who is a captain in the Royal Navy. Considerable information is given concerning reports which have been written by various German marine scientific workers since the capitulation, and it is expected soon to start upon the issue of a periodical wherein such reports will be printed for circulation.

\section{National Foundry College}

THe National Foundry College has been established and its board of governors nominated by the Minister of Education. The College will be housed in, and work closely in conjunction with, the Wolverhampton and Staffordshire Technical College. The board of governors is eharged with the responsibility for providing national facilities for foundry education and research, in the form of full-time courses, vacation courses, refresher courses, and the like, and also for providing regional and local facilities for full-time, part-time day and evening courses, to cover the whole range of foundry education. Its first task will be the re-establishment of the full-time diploma course which was the main feature of the predecessor of the College, the British Foundry School, during 1935-39. This course will normally run for an academic year, and the first session opens on January 5. The course will cover the whole of the foundry industry, ferrous and non-ferrous, including grey, white and chilled iron castings, malleable castings, steel castings, and castings in non-ferrous metals, such as alloys of copper, tin, zine, nickel, aluminium and magnesium. The diploma awarded to successful students will be endorsed by the Ministry of Educa. tion. There is no upper age limit for admission; a minimum of one year's practical experience in at least one branch of the industry will be required, together with a Higher National Certificate or a university degree, preferably in metallurgy or engineering, or a grade of membership obtained by examination of a professional institution in engineering, metallurgy or chemistry. Mr. J. Bamford, who was in charge of the British Foundry School during 1935-39, and who has since held important managerial appointments in the industry, has been appointed head of the National Foundry College.

\section{Abstracts on Powder Metallurgy}

Hrthento available in private circulation only, Metal Powder Report is now issued at an annual subscription of $£ 37 s .6 d$. The report is a sixteen-page monthly abstract journal dealing solely with the production, treatment and use of metal powders, under the joint editorship of W. D. Jones and R. A. Hetzig. The use of such products in electronics, the metallization of glass and ceramic materials, iron driving bands, porous aluminium-base bearings, electrical contacts, magnetic materials, sintered plates for batteries, sparking plugs, and stainless steel powders for paints and lacquers, all of which are mentioned in the issues for September and October 1947, will give an indication of the surprising breadth of interest of this very new branch of metallurgy. All concerned with powder metallurgy in any of its aspects will find this publication of real use. It is available from Powder Metallurgy, Ltd., Commonwealth House, 1-19 New Oxford Street, London, W.C.1.

\section{Biological Abstracts}

A NEW section of Biological Abstracts (University of Pennsylvania, Philadelphia) will be published as from January 1948. The section ( $J$-Abstracts of 